\title{
STRONGMEN AND RELIGIOUS LEADERS IN JAVA: Their Dynamic Relationship in Search of Power
}

\section{Yanwar Pribadi}

State Institute for Islamic Studies (IAIN) Sultan Maulana Hasanuddin Banten, Indonesia; PhD Candidate at Leiden University, the Netherlands.

\section{Abstract}

The central purpose of this paper is to explore the dynamic relationship between Javanese strongmen and religious leaders in search of power. Two groups of strongmen-jago in Central and East Java and jawara in Banten - and religious leaders, such as kyai, tarekat teachers and guru ngaji are the subjects of this discussion. I present two groups of strongmen and religious leaders and sketch how both groups, through their socio-political as well as religious roles, preserve the values of the Javanese and Bantenese. Religious leaders and strongmen have been the source of informal traditional leadership, particularly in villages. Religious leaders have represented leadership in knowledge, while strongmen have represented leadership with regard to braveness and physicalmagical power. The most visible roles of the strongmen are as power brokers. In the meantime, religious leaders have to be aware of the risk of being alienated and isolated from their horizontal networks within religious circles, but also more importantly, that their high position in society will gradually fade away if they place themselves too close to strongmen and the authorities.

Keywords: Jago, jawara, kyai, power relations

\section{A. Introduction}

Rural people in Indonesia are vulnerable. In Java, during the Dutch colonial period, there was enough population pressure to keep incomes 
low and underemployment common. People in the countryside were poorly connected with each other. During this time when emigration was difficult and the protection of the central state uncertain, rural inhabitants remained eminently vulnerable. At this time, banditry was rampant and strongmen took advantage of weak law enforcement, challenging the reputation of the island as a place of safety. Moreover, it was the colonial authority that to a large extent provided criminals with opportunities to maintain their power. ${ }^{1}$

Strongmen have been widely associated with bandits ${ }^{2}$, violent entrepreneurs ${ }^{3}$, or revolutionaries. ${ }^{4}$ In the Indonesian case, there have been several studies of these sturdy and muscular-stereotyped people who are represented as bandits ${ }^{5}$, village leaders ${ }^{6}$, intermediaries ${ }^{7}$, rebels $^{8}$ or local heroes, as well as power brokers, criminals and people who possessed magical power. ${ }^{9}$

Meanwhile, a strict distinction between the term ulama and kyai does not appear here. According to Noer, the term kyai might indicate

${ }^{1}$ Henk Schulte Nordholt, "The Jago in the Shadow: Crime and 'Order' in the Colonial State in Java," RIMA, Vol. 25/1, Winter 1991, pp. 74-91; Henk Schulte Nordholt, "A Genealogy of Violence," in Freek Colombijn and J. Thomas Lindblad (eds.), Roots of Violence in Indonesia: Contemporary Violence in Historical Perspective (Leiden: KITLV Press, 2002), pp. 33-61; and Henk Schulte Nordholt and Margreet van Till, "Colonial Criminals in Java, 1870-1910," in Vicente L. Rafael (ed.), Figures of Criminality in Indonesia, the Philippines, and Colonial Vietnam (Ithaca: Cornell Southeast Asia Program, 1999).

${ }^{2}$ Eric Hobsbawm, Bandits (New York: Delacorte Press, 1969).

${ }^{3}$ Anton Blok, The Mafia of a Sicilian Village 1860-1960: A Study of Violent Peasant Entrepreneurs (Oxford: Polity Press, 1988).

${ }^{4}$ John S. Koliopoulos, Brigands with a Cause: Brigandage and Irredentism in Modern Greece 1821-1912 (Oxford: Clarendon Press, 1987).

${ }^{5}$ Suhartono, Bandit-bandit Pedesaan: Studi Historis 1850-1942 di Jawa (Yogyakarta: Aditya Media, 1995).

${ }^{6}$ Onghokham, "The Inscrutable and the Paranoid: An Investigation into the Sources of the Brotodiningrat Affair," in Ruth McVey (ed.), Southeast Asian Transitions: Approaches through Social History (New Haven and London: Yale University Press, 1978), pp. 112-157.

${ }^{7}$ Onghokham, "The Jago in Colonial Java, Ambivalent Champion of the People," in Andrew Turton and Shigeharu Tanabe (eds.), Histroy and Peasant Consciousness in South East Asia (Osaka: National Museum of Ethnology, 1984), pp. 327-343.

${ }^{8}$ Robert Cribb, Gangsters and Revolutionaries: The Jakarta People 's Militia and the Indonesian Revolution 1945-1949 (North Sydney: Asian Studies Association of Australia, 1991).

${ }^{9}$ Henk Schulte Nordholt, "The Jago in the Shadow".. 
two kinds of persons. The first comprises those whose knowledge of Islam surpasses that of the ordinary men and typically devote themselves to teaching. The second type is more closely related to dukun (magicians/ shamans/medicine men/healer) who teach mystical and secret doctrines and practice all kinds of medicine. ${ }^{10}$ Horikoshi distinguishes the terms kyai and ulama. For Horikoshi the difference lies primarily in the more extensive charisma that a kyai possesses. The ulama play more of a role in the social system and the social structure of villages with their ultimate status legitimized by hereditary factors. Among the people, the kyai is higher than the village ulama and their presence is regarded as a unifying symbol in society since their moral and spiritual leadership is not tied to the normative structure of the village. ${ }^{11}$ In Madura the term kyai also signifies leadership in other realms. In the broader context the term ulama refers to men of Islamic learning and Islamic religious leaders in general. Hence, I use both terms, ulama and kyai interchangeably.

Exploring the dynamic relationship between Javanese strongmen and religious leaders in search of power is the purpose of this paper. Two groups of strongmen-jago in Central and East Java and jawara in Banten—and religious leaders, such as kyai, tarekat (mysticism) teachers and guru ngaji are the subjects of my discussion. In addition, tracing the historical roots of strongmen in Indonesia and their deeds is also one of the aims of this paper in order to raise our understanding of their nature, while discussions on religious leaders are not stressed here. In the following pages we will encounter jago and jawara who have also been considered as types of social protest and rebellion.

\section{B. Jago: Master of the Underworld}

Jago are undoubtedly the most notorious and discussed strongmen in the literature. A significant number of studies have examined jago as interested in violence, protest movements, and acting as power brokers or simply criminals in colonial Java, the Netherlands East Indies or Indonesia. While the term may offer a common identity for scholars working on subjects ranging from history, anthropology or sociology, it

${ }^{10}$ Deliar Noer, The Modernist Muslim Movement in Indonesia 1900-1942 (Kuala Lumpur: Oxford University Press, 1973).

${ }^{11}$ Hiroko Horikoshi, Kyai dan Perubahan Sosial (Jakarta: P3M, 1987). 
can also invoke a sense of anxiety from scholars of criminology, politics and area studies. It is not only that the term may be vague, but also that it can be abused. Since the term jago has been widely used and also mistreated, I am also concerned with how the term has been embedded and perceived in the literature dealing with subjects I have mentioned.

Jago literally means cock or fighting cock. The use of the word 'jago' does not always have negative connotations. In the contemporary period, one, for instance, can refer to a mathematician as 'jago matematika', although certainly to identify an infamous thug who commits crimes, one may use 'jagoan' (tough men). Though jago were notorious in colonial Java, almost every region had its own word to identify such figures, such as brengseng in Banyumas; warok in Ponorogo; bromocorab in Kediri; bangkerengan or gento in Tegal; lenggaong in Pemalang; jawara in Banten, Batavia and West Java; or pendekar as the most popular names. Lucas mentions:

"A lenggaong does not necessarily steal in the way an ordinary thief does. A lenggaong is a person who has physical strength, and deep spiritual knowledge. It takes a long time to become a lenggaong, studying self-defence arts (silat) and obtaining knowledge of inner things (ilmu-ilmu dalam). If a person has the title lenggaong, his livelihood does not come from stealing, but from other people who need the security of the protection that he can give... In colonial times the lenggaong were in general looked up to (disegani) by the people. Their actions did not bother the people. It was the colonial administration and the landlords who were obstructed."12

The historical roots of the jago lie in the pre-colonial period, during the time of royal wars and periods of violence in Javanese history. ${ }^{13}$ Their new roles, however, emerged and peaked during the colonial period.

Jago only existed in central and east Java. Similar groups in other regions definitely existed. Nonetheless, they had particular names. Some scholars have incorrectly addressed similar groups as jago. For instance, in Greater Jakarta area, the term jawara was used, instead of jago. ${ }^{14}$ Jago

${ }^{12}$ Anthony Edward Lucas, "The Bamboo Spear Pierces the Payung: The Revolution against the Bureaucratic Elite in North Central Java in 1945," PhD thesis (Canberra: Australian National University, 1981).

13 Onghokham, “The Jago in Colonial Java”, pp. 335-336.

${ }^{14}$ John R. W. Smail, Bandung in the Early Revolution, 1945-1946: A Study in the Social History of the Indonesian Revolution (Ithaca: Modern Indonesia Project, Cornell University, 1964); Robert Cribb, Gangsters and Revolutionaries; and Margreet van Till, "In Search of 
were more than simple rural criminals ${ }^{15}$ they were known mostly for their role as power brokers. The term jago is also frequently confused with jagoan. ${ }^{16}$ Indonesians may call present strongmen as jagoan, instead of jago. Jago is an adjective or noun to identify someone as being tough (in fighting) or smart (in science), for instance. Groups or an individual who act like jago are mostly called jagoan. This term has both positive and negative connotations. Although it seems unimportant, identifying a particular group with other names may be misleading and may lead to misunderstanding. Therefore, what I discuss here is the jago groups who roamed and settled in colonial Java.

In East Java jago found a comfortable haven, often acting as power brokers. They were also known as palang, kebayan, weri or blater. They were usually leaders of a peer group. Occasionally, a palang could surpass the charisma of a village headman. This charisma also extended to the population at large as well. ${ }^{17}$ Palang, however, did not enjoy their time of power for a long time. When the colonial administration ended Cultuurstelsel (Cultivation system) in 1870, the authorities removed palang from their previous function as agents for corvee labour. The function was replaced by weri who were employed by the Dutch administration to provide information to them. Weri thus acted as spies giving information about what was happening in villages. For the villagers, weri were called blater and this group numbered around 4.000 to 5.000 at the beginning of the twentieth century only in Madiun residency. ${ }^{18}$

Jago in their simplest form could also be criminals. Bands of robbers usually were led by a strong and sakti (posses magical power) boss. This headman formed a underworld network with other leaders of the similar groups. The networks as well as the bands were relatively loose in structure with individuals centred around a leader. The followers were hardly considered jago since there was only one 'jagoan' in a gang

Si Pitung: the History of an Indonesian Legend," in BKI 152, No. 3, 1996, pp. 461-482.

${ }^{15}$ John R. W. Smail, Bandung in the Early Revolution, p. 88.

${ }^{16}$ Nico Schulte Nordholt, "Violence and the Anarchy of the Modern Indonesian State," in Frans Hüsken and Huub de Jonge (eds.), Violence and Vengeance: Discontent and Conflict in New Order Indonesia (Saarbrücken: Verlag für Entwicklungspolitik Saarbrücken, 2002), pp. 53-54.

${ }^{17}$ Onghokham, “The Inscrutable and the Paranoid”, p. 74.

${ }^{18}$ Ibid, pp. $74-75$. 
though networks of jago were structurally common. These individuals or anak buah (underlings) could move to other gangs and took an oath to be faithful and serve their new leader if the old gang was disbanded or the leader was captured or if they were convinced that the new group could provide them with more opportunities. Patronage was thus exceptionally evident within these bands. The leader preserved his position by dispensing material rewards to leading members of the group. Personal links between anak buah and the leader could exist and were characterised by a large degree of dependencies on the assistance of the leader to the anak buah.

Like the notorious bandit Pitung in Batavia, jago were not righteous thugs. Jago, when they committed crimes with their bands, did not rob from the well-off and distribute the booty to the unfortunate. Farmers or peasants in general, were easy prey for criminal bands. Cattle rustlings were quite common in Pasuruan, for instance. In 1909 there were 1382 cattle rustlings, while the number dropped off to 778 in 1914, 189 in 1919 and only 63 in $1924 .{ }^{19}$ The number continuously declined for one main reason. Sugarcane (tebu) estates were introduced by Chinese landlords who had leased the land from various regents since the last decade of eighteenth century. One of these Chinese entrepreneurs was Han Kik Ko (1766-1813), the fifth son of Captain Han Bwee Kong whose estate around 1808 was including twelve villages and 2.538 persons. ${ }^{20}$ During the heyday of the estates, a considerable number of people earned money by renting their cattle-carts to the estates as their means of livelihood. The abundance of cattle attracted bands of robbers to operate in Pasuruan. The development of transportation at the beginning of the twentieth century, however, reduced the significance of cattle-carts. Consequently, cattle rustlings became less common. ${ }^{21}$

In another form of crime, jago might commit various kinds of extortion. Even though fairly loose in structure, the jago bands had their own territory with a hierarchy of leaders and sponsors and characterized by a distinct specialization of functions. Meetings in amusement centres, such as opium dens, prostitution quarters or simply warung (food stalls)

${ }^{19}$ Suhartono, Bandit-bandit Pedesaan, p. 148.

${ }^{20}$ Claudine Salmon, "The Han Family of East Java: Entrepreneurship and Politics (18th-19th Centuries)," Archipel, Volume 41, 1991. pp. 53-87.

${ }^{21}$ Suhartono, Bandit-bandit Pedesaan, p. 147-148. 
served as the occasion for discussing their plans. They arranged operations of extortion. Jago were aware that the colonial authority was unable to penetrate into the lowest level of administration, the village. Daendels had created a centralistic government. All government affairs were arranged from Batavia. The colonial government based the administrative mechanism on a Western model, placing sultans and their families under the Dutch colonial government, and converting them into bureaucrats. Daendels's purpose was to run the government under direct rule, so that he could rule the people without the local rulers as intermediary. However, the effect of this policy was not great. After the Daendels era, or more precisely after the Java war, the Dutch colonial government seemed to look back to indigenous people to run lower administrative areas where the indigenous administrative system relied on personal relations. The village became the lowest administrative unit, and was headed by a chief paid with a plot of village land. During this so-called indirect rule, jago offered "protection" to a certain village. As a result, the village was safe from cattle rustlings or ordinary robberies. This protection was not free and indicates the most notorious form of extortion committed by jago.

As extortionists, jago also committed the crime in more soft and elegant ways. They would not undertake any misdeeds in a certain village and in fact would "protect" the neighbourhood against robberies. This offer once again was not for free. In exchange, they received exemption from taxes. For being guardians, they were admired by the people. ${ }^{22}$ Not surprisingly, since they knew many of these defenceless elements of villagers, a number of jago could manage to become village heads by utilizing their role as the village guardians. Consequently, those villages were controlled by generations of jago who benefitted from the situation. ${ }^{23}$

Jago also acted as power brokers or intermediaries for there were increasing demands for such persons at all levels of society. Intermediaries appeared between cultural ideals and the political realities of governing a society, bridging an ideological gap. The aristocracy's ideal, and the ideal of all formal power holders in Java, was one of a symbolic centre, protective, passive and aloof from day-to-day affairs. Javanese ideology presented the noblemen as a parasitical but rather harmless class. Just

${ }^{22}$ Henk Schulte Nordholt, "The Jago in the Shadow", p. 82.

${ }^{23}$ Ibid, p. 84. 
as the demands of the Dutch and the aristocracies could not be fulfilled without active intermediaries, as they lacked personnel, the peasantry also saw a need for more active leadership in order to link them with the outer world. This was found in the jago. Relative distance from the formal focus of power gave intermediaries less need for charisma, and more scope for direct action. ${ }^{24}$ An intermediary is well illustrated in Groneman`s Een Kètjoegeschiedenis. ${ }^{25}$ Another figure is portrayed not only, for instance, as being wealthier than a village head, but also as more than an ordinary thief. He is fully aware of what he is doing since he is respected by the villagers. ${ }^{26}$

When they acted as brokers, jago normally operated against the population and they succeeded in spreading fear among the local inhabitants in colonial Java. ${ }^{27}$ Regents in Java had to come to an agreement with jago in their territory. As a result, jago in this way became the spies of the regents in their area and they would not be afraid to accept the role of the strong arm of the law. ${ }^{28}$ Jago were almost always useful as spies and collaborators of regents. Therefore, they succeeded in remaining beyond the reach of European administration and creating their own power base in the shadow of the colonial state. ${ }^{29}$

The colonial administration was concerned with the increasing roles of the jago. Batavia, for instance sent Snouck Hurgronje to Madiun to investigate a case involving the regent, Brotodiningrat. Snouck found several leaders of the jago, among them kyai and dukun. According to Snouck all these prominent jago had the reputation of being kebal (invulnerable) and taught others the means to achieve invulnerability. Although it would be hard to prove their involvement in any subversive designs of the regent of Madiun, or of any crime, Snouck advised the government to exile the most prominent jago. According to Snouck they had the reputation of being fearless even against higher Dutch authority and being kebal against bullets and sharp weapons. If the Netherlands East Indies government did not take measures against them, then their

\footnotetext{
${ }^{24}$ Onghokham, “The Jago in Colonial Java”, p. 337.

${ }^{25}$ Isaac Groneman, Een Kètjoegeschiedenis (Dordrecht: J.P. Revers, 1887).

${ }^{26}$ Boeka (P.C.C. Hansen Jr.), Pàh Troeno (Amsterdam: F van Rossen, 1901).

${ }^{27}$ Henk Schulte Nordholt, A Genealogy of Violence, pp. 39-40.

${ }^{28}$ Henk Schulte Nordholt, The Jago in the Shadow, p. 78.

${ }^{29}$ Ibid, p. 85
} 
reputation of being magically invulnerable would be enhanced and lead to more unrest. ${ }^{30}$

A Jago often gained his reputation from the fear he inspired in the local inhabitants. Once he had proven his power, people would not dare to oppose his nasty reputation. The official local rulers were aware of this situation. For them jago were the prime instrument to reinforce their grip on their district. Thus, besides the official hierarchy of local rulers, an indispensable informal circuit operated, in which jago operated as agent for the higher authorities. ${ }^{31}$ Furthermore, even though officially jago were considered to have played only a minor role, in reality they engaged in a more significant role at the center of local life, utilizing the space provided by the central government and filling it with violence. Local violence was part of an almost steady tradition in Java since, until recently, no central administration had the power to control society completely. ${ }^{32}$

\section{Jawara: Feared and Admired Champions ${ }^{33}$}

Perhaps the most influential strongmen group in the socio-political world of Indonesia is jawara. The New Order regime provided them with opportunities to expand themselves into socio-political realms. Era Reformasi, often characterized by social instability and insecurity, even has placed the position of this group on a firm basis. Jawara have long entrenched themselves in Bantenese society. Like jago, the roots can be traced back to the colonial era. Unlike jago, however, jawara have strengthened their position in society.

Throughout history, jawara in Banten played many roles, from their mythical origins as bodyguards of kings and ulama, to instigators of rebellions, to their mobilisation as security personnel for political parties and the ruling elite. Kartodirdjo argued that the jawara consisted largely of people without permanent occupation who were often engaged

${ }^{30}$ Onghokham, "The Jago in Colonial Java”, p. 328.

${ }^{31}$ Henk Schulte Nordholt, The Jago in the Shadow, p. 77.

${ }^{32}$ Ibid.

${ }^{33}$ Some parts of this section appear in my MA Thesis. See Yanwar Pribadi, "Jawara in Banten: Their Socio-Political Roles in the New Order Era 1966-1998," MA Thesis (Leiden: Leiden University, 2008). 
in criminal activities. ${ }^{34} \mathrm{~A}$ report from a Dutch resident, Craemer, in his memorie van overgave of 1930s, told us that jawara originally evolved from orok lanjang, a youth organization in the district of Menes. This organization then developed, spreading outside Menes and becoming known for providing bodyguards and being involved in fighting and stirring up trouble. ${ }^{35}$

The emergence of jawara was not a result of oppression and grinding poverty in Banten. Though they may have joined in spontaneous food riots, or may have committed criminal acts, people facing starvation are too busy just surviving to plot the overthrow of government or to formulate a blueprint for an alternative social order. ${ }^{36}$ The emergence of the jawara supports this proposition as well as the assertion that the potential for violent social protest corresponds to relative rather than absolute deprivation. Jawara groups who were considered to be bandits were reduced to starvation or to total impoverishment, suffering a significant decline in their social standing and economic well-being.

Moreover, their relationship with the rural population was ambiguous, as can be seen in the ambiguity of the jawara figure in folk etymology - which can also be considered to be an abbreviation - with words like jahat (evil), wani (brave), rampog (robber) and jago (champion), wani, (brave), and ramah (friendly). Else Ensering classified jawara into two groups: the jawara-teri, refering to petty thieves and robbers, and the jawara-gedeh, who practiced pencak silat, used weapons, and pursued mystical development under the guidance of a kyai, culminating in the

${ }^{34}$ Sartono Kartodirdjo, The Peasants' Revolt of Banten in 1888, Its Conditions, Course, and Sequel: A Case Study of Social Movements in Indonesia ('s-Gravenhage: Martinus Nijhoff, 1966).

${ }^{35}$ Arsip Nasional Republik Indonesia, Memori Serah Jabatan 1931-1940 Jawa Barat (I) (Jakarta: Penerbitan Sumber-sumber Sejarah No. 11, 1980). Furthermore, Williams stated that this organization was originally a mutual aid society which had its own administration, treasurer and local branches. Some branches had their own president and secretary with members paying monthly contributions. See Michael C. Williams, Communism, Religion and Revolt in Banten (Athens: Ohio University Center for International Studies, 1990), p. 281.

${ }^{36}$ E. J. Hobsbawm, Primitive Rebels: Studies in Archaic Forms of Social Movement in the 19th and 20th Centuries (New York: Norton, 1965), p. 79. 
attainment of invulnerability. ${ }^{37}$

Long after Indonesian independence, the patron-client relationship in Banten in the New Order Era perhaps was best identified in the ties between the state and jawara. Throughout history, jawara had always worked individually or in small bands. While there were informal networks of individual jawara, usually based upon allegiances and loyalties to particular ulama, there had never been a formal structured organization. Satkar Pendekar, renamed Persatuan Pendekar Persilatan dan Seni Budaya Banten Indonesia/PPPSBBI (the Indonesian Association of Bantenese Men of Martial Arts, Art and Culture), was established as a forum for jawara and martial arts schools throughout Banten as well as in Jakarta. From its inception PPPSBBI identified "nation and state" with Golkar, with whom they had had a close relationship starting with the 1977 general election. It was largely due to the influence of Tubagus Chasan Sochib who, from the early 1970s, was a local parliamentarian for the Golkar faction, and certainly a prominent figure in the jawara community. ${ }^{38}$

Tubagus Chasan Sochib is unquestionably the most influential and renowned, as well as notorious, jawara in Banten at the moment. As an old man, people may assume that he is an ordinary veteran. He is indeed a veteran in the jawara world, entrepreneurship and a veteran in the sense that he comes from Generation 45, a revolutionary generation that struggled in Indonesian Revolution 1945-1949. Ratu Atut Chosiyah, the present governor of Banten Province is one of his daughters.

Sochib was born in Serang in 1930. He has three brothers, Tubagus Basuni, Tubagus Syatibi and Entus Sibli, and one sister, Ojah Faojah. They are all children of Tubagus Sochib and Nyi Ratu Rofiah. He attended several pesantren (Islamic boarding school) during his childhood. Of the pesantrens, the Pesantren Pani is in Jiput, Pandeglang was his first boarding school. He was entrusted to Kyai Cholil by his parents. During his stay, he showed braveness and intelligence, an attitude which would benefit his future career in many areas of society. In the revolutionary era, Sochib

${ }^{37}$ Else Ensering, "Banten in Times of Revolution," Archipel, Volume 50: Banten Histoire d une région, 1995, p. 149.

${ }^{38}$ Ian Douglas Wilson, "The Politics of Inner Power: The Practice of Pencak Silat in West Java," PhD Thesis (Perth: Murdoch University, 2003), pp. 257-258 and Okamoto Masaaki, "Local Politics in Decentralised Indonesia: the Governor General of Banten Province,” ILAS Newsletter, No. 34, July 2004, p. 23. 
went to Pesantren Cadasari, under the guidance of Kyai Icot. Shortly after his acceptance to that pesantren, he joined Hisbullah, a guerrilla warfare unit, whose commanders were Kyai Abdullah and Ayip Samin. After the revolutionary period came to an end, he embarked upon a more serious working life in 1967 (after a couple of years dealing with a number of small businesses) by providing logistical support to the Kodam Siliwangi. Two years later he founded a construction company, PT Sinar Ciomas Raya, which frequently won government tenders for road and market construction projects. His involvement spread to the Krakatau Steel State Company, and to tourism and real estate, while holding key positions in associations, such as the Regional and Central Chambers of Commerce and Trade (Kadin) and the Indonesian National Contractors' Association (Gapensi), putting his men on their local executive committees. ${ }^{39}$

The position of Sochib in the PPPSBBI as chairman is the peak of his vertical mobility. That he was a kepala kuli (chief labourer) and then gained a more respectable status by becoming an entrepreneur showed this mobility. After he had reached the top, he moved horizontally, increasing his social mobility. Even though PPPSBBI is not a wing organization of Golkar, the organization was essential in the political context of Golkar. Golkar was a crucial and strategic element for Sochib expanding his horizontal mobility. As a man with power, through Golkar he had a wide sphere to increase his political access. To strengthen his domination in Golkar, he placed jawara as cadres in the organization with the banyan tree as its symbol. These cadres held several important positions at the district and municipal levels. Apparently, those who had had experience as local officials were favoured by him. However, to be actively engaged in Golkar was not his choice in career, although in reality he was a member of the advisory board. For Sochib, Golkar was an instrument to expand and secure his business, not mainly a tool to obtain political power. ${ }^{40}$ Therefore, through Kadin and Gapensi, Sochib could control the companies operating in Banten, due to the fact that certifications from Kadin and Gapensi were necessary for government

${ }^{39}$ Okamoto Masaaki, Local Politics in Decentralised Indonesia, p. 23 and Khatib Mansur, Profil Haji Tubagus Chasan Sochib beserta Komentar 100 Tokoh Masyarakat Seputar Pendekar Banten (Jakarta: Pustaka Antara Utama, 2000), pp. 79-82.

${ }^{40}$ H. S. Suhaedi, "Jawara Banten: Kajian Sosial-Historis tentang Mobilitas Sosial Jawara," MA Thesis (Depok, Universitas Indonesia, 2006), p. 132. 
procurement. Sochib utilized this to coordinate projects in Banten and the coordination brought him more money. Another side to this situation is that it led jawara under his control to become his sub-contractors and share in his profits. ${ }^{41}$

The PPPSBBI was the first organization through which he spread his power in the political constellation, and this political constellation then became the vehicle for introducing him to a bigger business world than he had moved in before. One of the main purposes of the establishment of the PPPSBBI was to channel the aspirations of jawara away from selfinterest and criminality towards more 'constructive' activities, contributing to the New Order`s program of social and economic development. Encompassing over 70 perguruan and debus groups, by the mid-1990s the organization claimed a membership of 170,000 . In the words of Sochib, "in the past jawara only fought for themselves, their group or tribe, however via the PPPSBBI together we fight for the nation and the state". Commonly known as jawara pembangunan (development jawara), they worked to ensure Golkar's supremacy. Taking advantage of the longstanding influence of jawara in village life, Golkar, through General Ali Murtopo, utilized PPPSBBI to secure support for the party in Banten. In addition, as the general chairman of the pendekar ${ }^{42}$ organization and one of the executive committee members of Satkar Ulama (Satuan Karya Ulama-the Ulama Work Squad), Sochib could act as a bridge between the military, bureaucracy and Golkar, as well as the informal world of Banten. ${ }^{43}$

Nevertheless, Sochib's activities are not limited to jawara and the business world. One of the founders of two private universities, Universitas Sultan Ageng Tirtayasa (Untirta) ${ }^{44}$ and Sekolah Tinggi Agama Islam Syekh Mansyur (Staisman), and of the Banten Museum, he remains the head of the Serang branch of Generation 45. He has become

${ }^{41}$ Okamoto Masaaki, Local Politics in Decentralised Indonesia, p. 23.

${ }^{42}$ In order to avoid the negative image that had come to be associated with the term jawara, it was replaced with 'pendekar'. See Ian Douglas Wilson, The Politics of Inner Power, p. 258. However, Tihami who conducted research on jawara in 1992 did not agree with the term pendekar, due to the non-originality of the word pendekar in Bantenese languages. See the interview with Tihami in Khatib Mansur, Profil Haji Tubagus Chasan Sochib, p. 268.

${ }^{43}$ Ian Douglas Wilson, The Politics of Inner Power, p. 258

${ }^{44}$ Not long after Banten residency became Banten province in 2000, the university became a state university. 
powerful in all aspects of Bantenese life; thus outsiders appointed as top bureaucrats rely on him and his networks as a bridge to the Bantenese world. ${ }^{45}$

Another prominent jawara figure in Bantenese society is Maman Rizal. Like many other jawara, after mastering martial arts, he went to Jakarta to find better opportunities for his livelihood. In 1967, he began his political career by entering Sekber Golkar and later, in 1970, joined the MKGR (Musyawarah Kekeluargaan Gotong Royong-The Mutual Assistance Families Society), a wing of Golkar. After returning to Banten, he became a member of the Pandeglang branch of Golkar. In Pandeglang he was appointed Ketua Divisi Pemenangan Pemilu dan Pengkaderan (the Head of Winning the General Election and Forming of Cadres Division or simply the Success Team) in 1987-1988. His wide network, encompassing other jawara with many followers, was a basic reason for him to hold several important positions in Golkar. Therefore, his influence was seen as an essential factor for his position in Golkar. In addition, he also served as treasurer of MKGR from 1975 until 1987. His political career in Golkar gradually improved with his appointment as treasurer of the Serang branch of Golkar, from 1988-2000. For Rizal, Golkar had political and economical benefits that formed a structural base for broadening his power. As an entrepreneur, he has become involved in many government-financed projects. Meanwhile, in the jawara world, he is now a leading figure in the Kebudayaan Seni Tari dan Silat Indonesia Tjimande Tari Kolot Kebon Djeruk Hilir (Kesti TTKKDHthe Indonesian Dancing and Martial Arts Tjimande Tari Kolot Kebon Djeruk Hilir Association). ${ }^{46}$ This organization is widely known among the Bantenese, and thus facilitates spreading the organization to villages. Consequently, Kesti T'TKKDH contributed to the victories of Golkar during the New Order era's general elections. Golkar, however, rendered a service bestowing members of the organization positions in the local parliament, as well as conferring big favours on them to help them become successful entrepreneurs. Like Sochib, the economic aspect was

${ }^{45}$ Okamoto Masaaki, "Local Politics in Decentralised Indonesia", p. 23 and H. S. Suhaedi, Jawara Banten, p. 135.

${ }^{46}$ This organization was established in 1952 and has approximately 10 million loose members all over the country. It is an umbrella organization which covers all Cimande martial arts schools. 
a main reason behind his activities. ${ }^{47}$

In Cilegon the most prominent kyai who is also well known for having jawara attributes is K.H. Syafiq Latify, a kyai from pesantren AlJauharotun Naqiyyah. His reputation has expanded to Serang, Pandeglang and Lebak since he is frequently invited to give pengajian (religious gatherings) outside his hometown. It is customary in many regions in Indonesia where religious elements are highly regarded that government officials and entrepreneurs pay a visit - sowan-meminta petunjuk/asking guidance on various matters - to religious leaders. This kyai-jawara is one of the most visited kyai in Cilegon, as well as in Banten province. ${ }^{48}$

Latify is a member of Dewan Syuro PKB (Partai Kebangkitan Bangsa-the National Awakening Party). Through his influence, his son, H. Iskandar became head of the Cilegon branch of PKB. His other son, H. Ulfi, was installed as the branch manager of Ramayana Department Store - a leading chain store in Indonesia - utilizing his power. Numerous entrepreneurs of entertainment centres give upeti-japrem/illegal rent - to him for the security of their businesses. The local police are aware of this, but because of his great influence, the police seem to be indisposed to have words with him. ${ }^{49}$

Another major jawara in Cilegon is Abah Mustofa. He holds the position as the head of security for Kawasan Industri Cilegon (Cilegon Industrial Centre). His influence goes even further. He also controls other strategic places, ranging from entertainment centres to public beaches. ${ }^{50}$ The authorities are aware of these conditions, but instead of confronting the jawara, the authorities employ jawara's services to collect retributions.

These four examples of prominent jawara and their companies show us that jawara to a large extent have held important roles in colouring the socio-political aspects of Bantenese life. Furthermore, despite their dependence on the central government, regional governments were relatively powerful in terms of local administration because they offered employment and channelled government funds. This facilitated the

${ }^{47}$ H. S. Suhaedi, Jawara Banten, p. 137-140.

${ }^{48}$ Oji Armuji, "Konfigurasi Kekuasaan Elit Lokal: Dinamika Ulama, Jawara dan Penguasa di Kota Cilegon (Masa Orde Baru, Masa Transisi, dan Pasca 2000)," MA Thesis (Yogyakarta, Universitas Gadjah Mada, 2004), p. 109.

${ }^{49}$ Ibid.

${ }^{50}$ Ibid, p. 110. 
reproduction of patrimonial patterns of rule at the local level, especially in Banten. Even though jawara as the local elite had access to central state agencies, they also relied on local constituencies that were mobilized through ethnic loyalties.

Patron-client relationship between jawara and the state is also accurately illustrated here:

"Even though our operations are not official, actually we obtain this power from the authorities (orang-orang di atas). What we do is no more than our "obliged responsibility" with sufficient material rewards in exchange. We also carry out "special orders" (pesanan-pesanan khusus) that require the masses and forcing power towards other parties. The ties are not comprehensibly arranged, except with sides who can assure great benefits. We consider it as more appropriate than being robbers, thieves or pickpockets (Apang, a jawara whose territory is in Anyer beach). ${ }^{51}$

The relationship between authorities and jawara depends on mutual understanding, especially in economic sectors, although during general elections political considerations of this mutual understanding are more noticeable. In many aspects, jawara become shields and protectors of entrepreneurs' businesses. In exchange, owners are "obliged" to fulfil jawara`s wishes, providing them with funds (japrem-jatah preman). This well illustrates what we know as perdek.kingan/perbekkingan - the backing system.

Muhit, another jawara in the shopping district of Cilegon underlines the similar importance:

"We do not collect retributions as much as we like. As a matter of fact, it is the authorities who give us conviction to arrange and be responsible in safekeeping matters. Our duty is only performing the commitment we make with the authorities. We give the results from the contributions and only take a little as our wage., 52

Apang and Muhit, unlike the four prominent jawara I mentioned earlier, are not easy to distinguish with preman. As jawara gedeh, the four figures do not actually resemble the preman characteristics. They are not petty thieves. Even though their operations, especially in Era Reformasi, have been portrayed as small kings who have transformed themselves into powerful local oligarchs through illicit means, they never personally
${ }^{51}$ Ibid, p. 141.
${ }^{52}$ Ibid, p. 138. 
use their otot (physical strength) to run their business. They mostly use threatening orders and intimidations. Their sangar (spooky) and cruel reputation was gained when they were still young and strong in physical sense. More importantly, they have placed themselves as power brokers, bridging the state and the underworld. Apang and Muhit and other jawara teri are under their command. If Apang and Muhit are the enforcers in the lower level, such as collecting money from angkot (public transportation means) drivers in their territory, these four jawara are the enforcers of the enforcers. It is their business to deal with the authorities in determining which areas belong to whom. Apang and Muhit may fit the criteria of jawara-like as Barker has suggested, but in my view, he does not reflect the type of jawara Banten, but closer to the preman. Thus, the jawara version of Barker is not comparable to the four jawara gedeh in Banten. ${ }^{53}$

The fall of Suharto in 1998 led to changes in the jawara world. Masaaki has emphasized the significance of jawara roles in Pilkada Banten 2006 - the 2006 Direct Election of Governor of Banten. In bringing about the victory of Ratu Atut Chosiyah, jawara groups under the leadership of Sochib made use of various means to bring this jawaralike strong minded and confident woman to become the first female governor of Banten. The various methods ranged from publicizing the results of two polls conducted by Lembaga Survei Indonesia (Indonesian Survey Institute) and Lingkaran Survei Indonesia (Indonesian Survey Circle), to intervening in Golkar`s regional convention on 2 July 2006 as well as performing the same actions in PDI-P`s special regional working meeting on 5 April $2006 .{ }^{54}$ They also capitalized on voters' materialism, ${ }^{55}$ utilizing PPPSBBI and Badan Pembina Potensi Keluarga Besar Banten (BPPKB-the Agency to Develop the Potentialities of the Bantenese), and co-opted young intellectuals, such as activists from Himpunan Mahasiswa Islam (HMI-Islamic Students' Association), Pergerakan Mahasiswa Islam

${ }^{53}$ See Barker`s description about jawara in Joshua Barker, "Surveillance and Territoriality in Bandung", in Vicente L. Rafael (ed.), Figures of Criminality in Indonesia, the Philippines, and Colonial Vietnam (Ithaca: Southeast Asia Program Publications, Cornell University, 1999), pp. 119-122.

${ }^{54}$ The result is that Atut became the sole candidate for the governor seat from the two major parties.

${ }^{55}$ Ranging from jual-beli suara/sell-buy votes before the election day until executing serangan fajar-dawn attack/the buying of votes at dawn on the election day 
Indonesia (PMII-Indonesian Islam Student Movement) and Komite Nasional Pemuda Indonesia (KNPI-National Committee for Indonesian Youth)..$^{56}$ The last strategy actually mirrored the tactics that Golkar used during the Suharto regime in gaining victories during general elections.

\section{Strongmen and Religious Leaders: Contesting a Complex Relationship ${ }^{57}$}

It seems that banditry was prevalent in Java because mostly as peasant protest. Banditry has even been identified as the simplest form of rebellion due to the difficulty it causes for the authorities. ${ }^{58}$ In peasant's protest, the role of informal leaders cannot be neglected. Religious leaders, such as kyai in pesantren or guru (religious teachers) often assume political leadership. They were extensively believed to posses mystical attributes and magical abilities that gave them charismatic power and a high social standing in society. Most bandits in Banten, who had been farmers before becoming robbers, usually learnt (berguru) ilmu - literally knowledge, though it can mean magical science or martial arts - in pesantren or other religious institutions, not only for religious ilmu, but undoubtedly also for ilmu kebal (invulnerability). Kyai had to be leaders of people whom the Dutch and later the Islamic modernist movement disliked, because they led them in a direction they considered narrow and conservative. ${ }^{59}$ We have to remember that in the course of few decades, in Banten, there was an intensification of fanaticism in pesantren circles and a hostile and aggressive attitude came to be ingrained into the santri (pupils of pesantren) towards both foreigners and the priyayi (aristocracies) ${ }^{60}$ However, it did not automatically turn the foreigners and nobles into victims. Most victims were simply farmers. Like Blok has suggested, bandits usually lived close to their victims. In fact, some of them lived

${ }^{56}$ Okamoto Masaaki and Abdul Hamid, “Jawara in Power, 1999-2007," Indonesia 86, October 2008, pp. 126-135.

${ }^{57}$ Some parts of this section appear in my $M A$ Thesis.

${ }^{58}$ Anton Blok, "Bandits and Boundaries: Robber Bands and Secret Societies on the Dutch Frontier (1730-1778,)" in Anton Blok (ed.), Honour and Violence (Cambridge: Polity Press, 2001), p. 29.

${ }^{59}$ Michael C. Williams, Communism, Religion and Revolt in Banten, pp. 57-58.

${ }^{60}$ Sartono Kartodirdjo, The Peasants' Revolt of Banten, pp. 154-157. 
in the same village and some were even close neighbours. ${ }^{61}$ Bandits directed their actions against property and people. Forms of violence were embodied and were common. Even if bandits acted against the rich, they did not give their booty to the poor. One of the most legendary bandit figures in colonial Java, the notorious Pitung, operated in Batavia and was romantically depicted as the Indonesian Robin Hood, a hero struggling against the corrupt coalition between the local aristocracies and the Dutch administration. In reality, he was no more than a common robber, an outlaw, as I mentioned before. After his death, he in fact became more famous as stories, ballads and lenong performances - popular traditional plays in Jakarta - have passed down his tales. However, no evidence has been found that Pitung distributed his loot to the poor. ${ }^{62}$ The Hobsbawm`s romanticized social bandits were far from reality.

Even though bands of robbers could be very violent, they were inclined to use non-violent methods in their operation. Violent actions appeared if there was no other way to avoid it. They preferred to use several kinds of mantra and other variants of magical-mystics to cast deep sleep on their victims (aji sirep). Several mantras to shed sleep existed, but most primbon - Javanese sources of supra-natural knowledge - gave the impression that ilmu begananda was thought to be the most effective one. Cautious thieves also complied with spirits, particularly ancestral spirits, guardian spirits and those spirits believed to watch over certain days of the week. The leaders were usually thought to be endowed with mystifying powers, with followers having a strong conviction that their leaders were really able to emanate magical powers. They were also equipped with jimat (amulet, charm), some of those came from religious guru, to reject bad luck and evil spirits directed at them. ${ }^{63}$

The idea of charisma is well-known in Indonesian society. It was not only the religious elites who were assumed to possess charismatic power, but also underworld leaders. Leader-follower relations in bands of robbers mirrored those of guru-murid (teachers-disciples) in religious circles of the pesantren or tarekat world, allowing the leaders to enhance

${ }^{61}$ Anton Blok, Bandits and Boundaries, p. 33.

${ }^{62}$ Margreet van Till, "In Search of Si Pitung".

${ }^{63}$ P. M. van Wulfften Palthe, Psychological Aspects of the Indonesian Problem (Leiden: E.J. Brill, 1949), pp. 27-28; Suhartono, Bandit-bandit Pedesaan, p. 102; and George Quinn, "The Javanese Science of Burglary," RIMA, 9, 1, January-June 1975, pp. 47-48. 
their power. Bandit chiefs usually possessed jimat which provided them with invulnerability and invisibility through qiarah (pilgrimages) to holy graves or holy places, such as gunung keramat (sacred mountain), huge and old trees or big stones. Ziarah to those sites was also thought to indicate the time when robberies may be committed or the methods to execute the burglary. Due to the charisma possessed by the leaders, the followers became loyal and obedient to them. A benggol, (a leader of a band of robbers) in rural Java frequently led his gang until he was too old to be in charge of his band or until he died.

One of the most common relations between strongmen and religious leaders is the fact that jago might learn pencak silat (martial arts) with a certain guru. It is also possible that they knew a few simple Arabic words. In colonial Pekalongan, there were many kyai in the rural areas who were sakti and were able to transfer the ilmu, reflecting the strong magic-religious elements in rural Islam..$^{64}$ Lenggaong, a jago-like group in Pekalongan, Brebes and Tegal were deeply involved in the rural revolution in October 1945. They were to a large degree tied to Islam. ${ }^{65}$ Elsewhere, militia groups in the Greater Batavia area also mastered silat skills, including ilmu kanuragan (invulnerability). Unlike common jago who were not dukun, these revolutionaries could also create jimat with the same amount of kesaktian. ${ }^{66}$

Meanwhile, in religious circles of Java, the additional economic benefit of some villagers facilitated kyai in financing their pesantren. Kyai and other religious figures, such as guru ngaji (teacher of Quran reciting), imam (leader of prayer), juru kunci (caretaker in a graveyard), merbot (gatekeeper of mosque), modin (muezzin), and naib (sub-district pangulu), in short, those who were involved in arranging the religious life in villages, including in maintaining pesantren, appeared to hold a higher position among village inhabitants. They were needed especially during ritualistic festivities, such as kenduri to commemorate the dead and slametan. Moreover, some kyai, besides showing their capacity as men of learning in Islam, also performed mystical Islam, such as predicting the future, healing people's illnesses and giving martial arts lessons. The

${ }^{64}$ Anthony Edward Lucas, “The Bamboo Spear Pierces the Payung”, pp. 37-38.

${ }^{65}$ Ibid, p. 164.

${ }^{66}$ Robert Cribb, Gangsters and Revolutionaries, p. 20. 
supernatural powers, drawn from mystical Islam, were indeed important attributes to develop power and authority relations. Because of these abilities, many jago visited kyai and asked for guidance. This high standing of kyai was found in nineteenth century Java, as well as in other places in the Netherlands Indies.

Religious leaders in Java gradually reinforced their status among the local population. After the East Indies were placed under the authority of Governor-General Herman Willem Daendels in 1808, he reorganized the administration on the orders of King Louis Napoleon, the ruler of the newly established Kingdom of Holland ${ }^{67}$ Under pressure from the Dutch colonial administration, the local elite were slowly incorporated into the Dutch colonial administration during the nineteenth century. For religious figures and many villagers, it meant that the elite also allied themselves with the infidel power of the Dutch. As a result, religious leaders, along with villagers experienced disappointment and dissatisfaction since they had viewed the elite as autonomous, ideal and influential leaders. The people then searched for others who might be able to give guidance for achieving harmony in life. In fact, the earlier local elite had enjoyed good relations with prominent religious figures since they were not willing to acknowledge the authority of rulers recognised by VOC. They turned to religion in order to preserve their high place in society. This situation changed in the nineteenth century when they became a mere tool of the colonial bureaucracy.

However, people did not like it when their leaders were integrated into the colonial administration. Unlike the local elites, the religious figures, such as kyai succeeded in preserving their independence. Villagers gradually turned to religious figures. This does not mean that they occupied the central position among villagers after Daendels came into power. Instead, they became central local leaders in religious, spiritual and limited social matters. The decline of the local elite's legal leadership had a direct consequence: this led the ulama to reinforce their position in society. At relatively the same time, jago figures also experienced the same situation. The changing pattern of the local hierarchy due to the Dutch colonial government in Java can be seen as the main factor in

${ }^{67}$ Ota Atsushi, Changes of Regime and Social Dynamics in West Java: Society, State and the Outer World of Banten 1750-1830 (Leiden and Boston: Brill, 2006), p. 143. 
strengthening the position of the ulama as religious leaders and jago as feared and respected informal leaders.

In Banten, jawara in the vast network of pesantren were influential in the spread of martial arts. Perhaps martial arts in Banten are closely intertwined with the life of tarekat. In some cases jawara joined tarekat as part of a sincere spiritual quest. Nevertheless, more commonly tarekat and the techniques that they were taught were means toward obtaining the various kinds of esoteric knowledge that were considered essential for success as jawara. Similarly, some martial arts teachers conducted tarekat type communal devotions. ${ }^{68}$

Ulama and jawara were co-opted into the political machines of Golkar. The recognition of ulama by the governing party can be seen in the establishment of Satkar Ulama in 1971, while jawara were organised into Satkar Pendekar (Satuan Karya Pendekar-the Martial Art Work Squad) in 1972. By entering the state and adjusting to the new atmosphere of the political situation, they created new positions where they gradually expanded their power, status and wealth.

Jawara were the pupils of kyai. Kyai in Banten not only taught Islamic religious learning, but also gave martial arts as one of the lessons. Pupils who were more talented in practising martial arts became known as jawara. Even though they left the pesantren after they graduated, they still considered the kyai as their teachers. Therefore, to oppose the kyai was a serious breach of etiquette, with both social and spiritual consequences, and expulsion from pesantren was a serious form of social ostracism. On a spiritual level, a rebellious pupil ran the risk of kawalat (accursed and therefore struck down by calamity).$^{69}$ Perhaps that is why a considerable number of jawara believed that they are the khadam (servant) of kyai.

The close relationship between jawara and ulama was crucial throughout the late nineteenth century, when revolts against the Dutch colonial government erupted throughout Banten, and again during the

${ }^{68}$ Martin van Bruinessen, "Shari' a court, tarekat and pesantren: Religious Institutions in the Banten Sultanate," Archipel, Volume 50, Banten Histoire d'une région, 1995, pp. 187-191.

${ }^{69}$ M. A. Tihami, "Kyai dan Jawara di Banten: Studi tentang Agama, Magi, dan Kepemimpinan di Desa Pasanggrahan Serang, Banten," MA Thesis (Depok: Universitas Indonesia, 1992), pp. 99-100 and Ian Douglas Wilson, "The Politics of Inner Power", p. 246. 
struggle for independence. Both were central figures in village life. The relationship between them was at times troubled, as jawara, to a large extent represented pre-Islamic traditions sometimes considered to be at odds with Islam. ${ }^{70}$ Between them, there were also intermediaries known as ulama jawara. This term could be applied either to jawara who had established themselves as religious teachers, or to ulama who had mastered martial arts. In either case such figures played an important role as mediating cultural brokers. ${ }^{71}$

Jawara played roles mainly with leadership aspects, such as becoming jaro (lurah-village head), jagakersa (penjaga keamanan desa-village security), martial arts teachers, and even teachers of magic. ${ }^{72}$ The jaro figures that first appeared during the reign of the Sultanate still existed in recent days. Certainly, during the New Order Era, these figures were well known for their leadership in mobilizing local villagers to vote for the ruling party in general elections. Jawara also became martial arts teachers as well as teachers of magic. Initially, these were the most obvious characteristics of jawara. Within jawara culture there is also a differentiation between 'black magic' and 'white magic' jawara. Those who traced their lineage to past jawara and sought to continue it through their own offspring were 'white', whereas those with no identifiable lineage were 'black'. The existence of a lineage was crucial to the legitimization of a jawara within his community. The lineage acted as a type of 'contract' of accountability to pre-established norms. The linking thread between the two types of jawara was the possession of supernatural power. In addition, the role of jawara which is associated with magic is as debus ${ }^{73}$ players. It is interesting to note that many jawara often took some verses from Quran, and thus they believed that the power they had originally came from kyai. ${ }^{74}$

${ }^{70}$ Ian Douglas Wilson, “The Politics of Inner Power”, p. 249.

${ }^{71}$ Sunatra, "Integrasi dan Konflik: Kedudukan Politik Ulama-Jawara dalam Budaya Politik Lokal: Studi Kasus Kepemimpinan Informal Pedesaan di Banten Selatan,” PhD Thesis (Bandung: Universitas Padjadjaran, 1997), p. 138.

${ }^{72}$ Hudaeri, "Tasbih dan Golok," unpublished article for the Ministry of Religious Affairs, 2002, p. 44.

${ }^{73}$ A traditional performance that its main function is to furnish proof of invulnerability. See, for instance J. Vredenbregt, "Dabus in West Java,” BKI 129 (1973), No. 2/3, pp. 302-320.

${ }^{74}$ Hudaeri, "Tasbih dan Golok", pp. 44-53; Ian Douglas Wilson, The Politics of Inner Power, p. 245; and Sunatra, Integrasi dan Konflik, pp. 100-101. 
Nonetheless, I argue that this view is somewhat misleading since both a considerable number of 'white' and 'black' jawara have used black magic up to the present day.

Both ulama and jawara are subcultures of the complete culture which makes up Bantenese culture. Ulama are well known as public figures in the socio-religious aspect, while jawara deal mainly with society in the social institutions of the Bantenese. Even though ulama and jawara played different roles during the New Order era, the integration between them through PPPSBBI and Satkar Ulama led them to be considered as belonging to the social elite within Bantenese society. ${ }^{75}$

Ulama and jawara are the source of informal traditional leadership, particularly in villages. Ulama represent the leadership in knowledge, while jawara represent the leadership with regard to bravery and physic-magical power. This kind of leadership cannot be neglected, and in fact it can be traced back to the Sultanate period. The long history of rebellions in Banten led the Bantenese to possess a unique character, characterized in society mainly by ulama and jawara. Therefore, the relationship between ulama and jawara has two special characteristics: the integrative and the disintegrative characteristic.

In the integrative social relationship, jawara need ulama as religious figures as well as for magical power. Ulama are seen as the most important legitimizing tool in jawara's leadership. Without support from ulama, jawara will have difficulty in becoming informal leaders. In societies like the Bantenese, which consider religion as guidance, approval from ulama will lead society in its choice of leaders. Therefore, jawara always need support from ulama if they want to become leaders.

Jawara are also dependent on ulama in issues of magical sources. It is widely believed in Banten that ulama possess 'Islamic magic' and that jawara gain their fighting skills from ulama. Hence, many jawara consider themselves as servants of ulama. On the other hand, ulama have several interests in jawara, mainly their physical and material support. Jawara who ask for martial arts and magic from ulama will surely give material compensation, such as money or valuable gifts, which are known as salawat. Giving salawat to ulama is meant as payment for an ulama's blessing

${ }^{75}$ Edi S. Ekadjati, Kebudayaan Sunda: Suatu Pendekatan Sejarah (Jakarta: Pustaka Jaya, 1995), p. 224 and Sunatra, Integrasi dan Konflik, p. 131. 
given to jawara. ${ }^{76}$

I argue that this unique relationship between ulama and jawara was evident during the New Order era. Golkar utilized its affiliated associations, such as the Indonesian Renewal Youth Organisation (AMPI-Angkatan Muda Pembaharuan Indonesia), National Committee for Indonesian Youth (KNPI-Komite Nasional Pemuda Indonesia) and Siliwangi Youth (AMS-Angkatan Muda Siliwangi) to secure support for the party. In Banten, where local politics was dominated by ulama and jawara, they made use of Satkar Ulama ${ }^{77}$ and PPPSBBI to gain victories. In this respect Golkar mirrored the tactics used by the PKI. They found out that the feelings of the Bantenese towards ulama were those of respect, while towards jawara they were a mixture of fear and respect. Therefore, to a large extent the integration between ulama-jawara and the people could happen due to the support of almost all of the elements in Banten who believed in the power of the two social groups, and respected them up to recent days, as well.

\section{E. Conclusion}

Religious leaders in Indonesia respond in various ways to ideological and political developments partially because in each area they relate to localized political situations. In present Indonesia, religious life has not been integrated into the political state. Therefore, it is not surprising to note that a considerable number of religious leaders in Indonesia, at least in the modern period, are not affiliated with bureaucracy. However, they continue to occupy important roles in Indonesia.

In colonial Java, ulama emerged as important religious leaders as well as the people's leaders due to the Dutch colonial administration and the integration of the local secular elite into the foreign power. The desire of many villagers for leaders who provided their philosophical base in their daily life was manifested in the relationship between the people and influential leaders who successfully maintained their independence. Religious leaders were seen as people's leaders in almost all aspects of

${ }^{76}$ M. A. Tihami, "Kyai dan Jawara di Banten”, p. 103.

${ }^{77}$ For the involvement of Mathla ul Anwar, one of the largest Muslim massbased organizations in Indonesia, in Golkar, see Didin Nurul Rosidin, "From Kampung to Kota: a Study of the Transformation of Mathla ul Anwar 1916-1998”, PhD Thesis (Leiden: Leiden University, 2007). 
villager life.

In the traditional life of Java and Banten, extraordinary people such as kyai are needed to serve as the ultimate leader. The priyayi who were seen as mere officials of a foreign administration and their successors who, after independence, were perceived as agents of a secular state, are not the ideal propagators and guardians of Quran and other written materials. Thus, the intellectual ability to understand these sources has to belong to the right people. In this respect, the Javanese gradually turned to religious figures and the decline of the local elite leadership led the ulama to strengthen their position in the society.

In Banten, Satkar Ulama, together with jawara, can also be seen as a determining factor in the process of local politics, where their influence went far beyond that of any other elements. The integration of ulama-jawara and the people led Golkar to achieve victories in Banten. In Banten, ulama and jawara were both respected and feared figures because of their physic-magical power, and together they formed a unique combination supporting the New Order regime in Banten. This combination was strengthened by the support of local society among whom ulama were well-known figures in the socio-religious aspect, while jawara were considered by society as a social group within the Bantenese culture. Thus the integration of these two groups was able to exist for years, even up to the present day.

Furthermore, jago and jawara, whether they become power brokers or criminals, are outlaws, in the sense that the authorities do not wish to touch them. They can make alliances with criminals, but they can also cooperate with local administrations. Everything depends on the demands. They are needed by local authorities to maintain peace and order, but they will almost definitely collaborate with criminals if there are big targets and easy prey. Nevertheless, they mostly make allies with local authorities as their means of livelihood. During the colonial period, these local authorities who lost their privileges became their main allies. Since there were a significant number of local authorities who lost their privileges, not surprisingly, bands of these people could grow and expand their territory and alliances with local authorities. Certainly, to facilitate the coordination between them, these strongmen created their own networks. By establishing these loose networks, their position 
became stronger and complicated and thus created complex conditions for colonial authorities. Here we witness that the conditions that made these strongmen possible were due to the weak policies of the colonial administration to accommodate the interests of local and indigenous authorities as well as due to the weak law enforcement of both local and colonial administrations. These conditions did not occur all at once, but gradually, indicating a tendency that when colonial authorities' policies failed to facilitate indigenous people in creating strong economies and and strict laws, illegal and violent practices happen in society.

Unlike jago who slowly lost their influence after Indonesian independence, as long as the manifestation of 'law and order' was not openly disrupted, jawara have continued their business up to present day. In collaboration with and protected by local officials, several jawara have succeeded in positioning themselves as elites in social, political and economical domains of the Bantenese, where they have formed an unstable system of internally shifting power relationship which challenged the formal structures of the state. They are what we call the shadow state. ${ }^{78}$ The ongoing state formation, such as democratization and decentralization, allows for the emergence of politically autonomous local leaders. This process seems to enable, or-in fact - to maintain a number of deep-rooted social groups which use violence and intimidation as the means for reaching their goals. Like the mafia in Sicily, they are entrepreneurs of violence. They are brokers who are in the service of the authorities and against the population. They have extensive networks that maintain their position in society and the authorities make it possible for them to continue their practice of power.

Defining the relationship between strongmen and religious leaders is not an easy task. They have had a complex relationship for over a hundred years. During the colonial era, strongmen in Java needed religious leaders mostly for fighting skills and magical power. In the New Order period in Banten, jawara and religious leaders can also be seen as a determining factor in the process of local politics in Banten, where their influence went far beyond that of any other elements. Era Reformasi

${ }^{78}$ Henk Schulte Nordholt, A Genealogy of Violence, pp. 39-40 and Syarif Hidayat, "Shadow State'?: Business and Politics in the Province of Banten," in Henk Schulte Nordholt and Gerry van Klinken (eds.), Renegotiating Boundaries: Local Politics in Post-Subarto Indonesia (Leiden: KITLV Press, 2007). 
has witnessed the growing recognition of jawara groups in Banten. Even though they have been portrayed as small kings who have transformed themselves into powerful local oligarchs through illicit means, their dynamic relationship with religious leaders is still marked by obedience to religious figures and concurrently, contests for power are taking place as well. 


\section{BIBLIOGRAPHY}

Armuji, Oji, "Konfigurasi Kekuasaan Elit Lokal: Dinamika Ulama, Jawara dan Penguasa di Kota Cilegon (Masa Orde Baru, Masa Transisi, dan Pasca 2000)," MA Thesis, Universitas Gadjah Mada, 2004.

Arsip Nasional Republik Indonesia, Memori Serah Jabatan 1931-1940 Jawa Barat (I), Jakarta: Penerbitan Sumber-sumber Sejarah No. 11, 1980.

Atsushi, Ota, Changes of Regime and Social Dynamics in West Java: Society, State and the Outer World of Banten 1750-1830, Leiden and Boston: Brill, 2006.

Barker, Joshua, "Surveillance and Territoriality in Bandung," in Vicente L. Rafael (ed.), Figures of Criminality in Indonesia, the Philippines, and Colonial Vietnam, Ithaca: Southeast Asia Program Publications, Cornell University, 1999.

Blok, Anton, The Mafia of a Sicilian Village 1860-1960: A Study of Violent Peasant Entrepreneurs, Oxford: Polity Press, 1988.

----, "Bandits and Boundaries: Robber Bands and Secret Societies on the Dutch Frontier (1730-1778)," in Anton Blok, Honour and Violence, Cambridge: Polity Press, 2001.

Boeka (P.C.C. Hansen Jr.), Pàh Troeno, Amsterdam: F van Rossen, 1901. Bruinessen, Martin van, "Shari a court, tarekat and pesantren: Religious Institutions in the Banten Sultanate," Archipel, Volume 50, Banten Histoire d une région, 1995.

Cribb, Robert, Gangsters and Revolutionaries: The Jakarta People's Militia and the Indonesian Revolution 1945-1949, North Sydney: Asian Studies Association of Australia, 1991.

Ekadjati, Edi S., Kebudayaan Sunda: Suatu Pendekatan Sejarah, Jakarta: Pustaka Jaya, 1995.

Ensering, Else, "Banten in Times of Revolution," Archipel, Volume 50: Banten Histoire diune région, 1995.

Groneman, Isaac, Een Kètjoegeschiedenis, Dordrecht: J.P. Revers, 1887.

Hidayat, Syarif, "Shadow State'?: Business and Politics in the Province of Banten" in Henk Schulte Nordholt and Gerry van Klinken (eds.), Renegotiating Boundaries: Local Politics in Post-Subarto Indonesia, Leiden: 
KITLV Press, 2007.

Hobsbawm, E. J., Primitive Rebels: Studies in Archaic Forms of Social Movement in the $19^{\text {th }}$ and $20^{\text {th }}$ Centuries, New York: Norton, 1965.

----, Bandits, New York: Delacorte Press, 1969.

Horikoshi, Hiroko, Kyai dan Perubahan Sosial, Jakarta: P3M, 1987.

Hudaeri, "Tasbih dan Golok," unpublished article for the Ministry of Religious Affairs, 2002.

Kartodirdjo, Sartono, The Peasants' Revolt of Banten in 1888, Its Conditions, Course, and Sequel: A Case Study of Social Movements in Indonesia, 's-Gravenhage: Martinus Nijhoff, 1966.

Koliopoulos, John S., Brigands with a Cause: Brigandage and Irredentism in Modern Greece 1821-1912, Oxford: Clarendon Press, 1987.

Lucas, Anthony Edward, "The Bamboo Spear Pierces the Payung: The Revolution against the Bureaucratic Elite in North Central Java in 1945," PhD Thesis, Australian National University, 1981.

Mansur, Khatib, Profil Haji Tubagus Chasan Socbib beserta Komentar 100 Tokoh Masyarakat Seputar Pendekar Banten, Jakarta: Pustaka Antara Utama, 2000.

Masaaki, Okamoto, "Local Politics in Decentralised Indonesia: the Governor General of Banten Province," in IIAS Newsletter, No. 34, July 2004.

Masaaki, Okamoto and Abdul Hamid, "Jawara in Power, 1999-2007," Indonesia 86, October 2008.

Noer, Deliar, The Modernist Muslim Movement in Indonesia 1900-1942, Kuala Lumpur: Oxford University Press, 1973.

Onghokham, "The Inscrutable and the Paranoid: An Investigation into the Sources of the Brotodiningrat Affair," in Ruth McVey, Southeast Asian Transitions: Approaches through Social History, New Haven and London: Yale University Press, 1978.

----, "The Jago in Colonial Java, Ambivalent Champion of the People," in Andrew Turton and Shigeharu Tanabe (eds.), Histroy and Peasant Conscionsness in South East Asia, Osaka: National Museum of Ethnology, 1984. 
Quinn, George, “The Javanese Science of Burglary,” RIMA, 9, 1, JanuaryJune 1975.

Pribadi, Yanwar, "Jawara in Banten: Their Socio-Political Roles in the New Order Era 1966-1998,” MA Thesis, Leiden University, 2008.

Rosidin, Didin Nurul, "From Kampung to Kota: a Study of the Transformation of Mathla ul Anwar 1916-1998," PhD Thesis, Leiden University, 2007.

Salmon, Claudine, "The Han Family of East Java: Entrepreneurship and Politics (18th-19th Centuries)," Archipel, Volume 41, 1991.

----, "The Jago in the Shadow: Crime and 'Order' in the Colonial State in Java,” RIMA, Vol. 25/1, Winter 1991.

----, "A Genealogy of Violence," in Freek Colombijn and J. Thomas Lindblad (eds.), Roots of Violence in Indonesia: Contemporary Violence in Historical Perspective, Leiden: KITLV Press, 2002.

---- and Margreet van Till, "Colonial Criminals in Java, 1870-1910," in Vicente L. Rafael (ed.), Figures of Criminality in Indonesia, the Philippines, and Colonial Vietnam, Ithaca: Cornell Southeast Asia Program, 1999.

Schulte Nordholt, Nico, "Violence and the Anarchy of the Modern Indonesian State," in Frans Hüsken and Huub de Jonge (eds.), Violence and Vengeance: Discontent and Conflict in New Order Indonesia, Saarbrücken: Verlag für Entwicklungspolitik Saarbrücken, 2002.

Smail, John R. W., Bandung in the Early Revolution, 1945-1946: A Study in the Social History of the Indonesian Revolution, Ithaca: Modern Indonesia Project, Cornell University, 1964.

Suhaedi, H.S., "Jawara Banten: Kajian Sosial-Historis tentang Mobilitas Sosial Jawara," MA Thesis, Universitas Indonesia, 2006.

Suhartono, Bandit-bandit Pedesaan: Studi Historis 1850-1942 di Jawa, Yogyakarta: Aditya Media, 1995.

Sunatra, "Integrasi dan Konflik: Kedudukan Politik Ulama-Jawara dalam Budaya Politik Lokal: Studi Kasus Kepemimpinan Informal Pedesaan di Banten Selatan," PhD Thesis, Universitas Padjadjaran, 1997.

Tihami, M. A., "Kyai dan Jawara di Banten: Studi tentang Agama, Magi, dan Kepemimpinan di Desa Pasanggrahan Serang, Banten," $M A$ 
Thesis, Universitas Indonesia, 1992.

Till, Margreet van, "In Search of Si Pitung: The History of an Indonesian Legend,” BKI 152, No. 3, 1996.

Vredenbregt, J., “Dabus in West Java,” BKI 129 (1973), No. 2/3.

Williams, Michael C., Communism, Religion and Revolt in Banten, Athens: Ohio University Center for International Studies, 1990.

Wilson, Ian Douglas, "The Politics of Inner Power: The Practice of Pencak Silat in West Java," PhD Thesis, Murdoch University, 2003.

Wulfften Palthe, P. M. van, Psychological Aspects of the Indonesian Problem, Leiden: E.J. Brill, 1949. 